\title{
Field inoculation of rice with in vitro selected plant-growth promoting-rhizobacteria
}

\author{
N. Omar ${ }^{1}$, Th. Heulin ${ }^{2}$, P. Weinhard ${ }^{2}$, M.N. Alaa El-Din ${ }^{1}$ and J. Balandreau 2 \\ 1 ARC, Soil and Water Research Institute, Giza, Egypt; \\ 2 CNRS, laboratoire d'écologie microbienne de la rhizosphère, centre de pédologie biologique, BP 5, 54501 Vandœuvre-les-Nancy, \\ France
}

(received 16 December 1988, accepted 1 June 1989)

\begin{abstract}
Summary - In a previous study of two Egyptian soils a great diversity of $\mathrm{N}_{2}$-fixing bacteria was found in the dominant microflora of the rhizosphere of rice. Under gnotobiotic conditions, strain NO40 of Azospirillum brasilense was more efficient than most isolates. NO40 was used under field conditions in 2 locations in the Nile delta for inoculating rice at sowing and at transplanting. In both locations, inoculation significantly increased yield $(0.01<P<0.05)$. These increases were higher at higher rates of nitrogen fertilization, and reached 15 and $20 \%$ at the Sakha and Gemmeiza experimental stations, respectively. Late components of yield were more affected.
\end{abstract}

PGPR - Azospirillum brasilense - spermosphere model - yield - inoculation

Résumé - Inoculation du riz, au champ, par des PGPR sélectionnées in vitro. Dans 2 sols égyptiens précédemment étudiés, une grande variété des bactéries fixatrices d'azote avait été mise en évidence dans la rhizosphère du riz, ainsi que de grandes différences quant à l'efficience de leur fixation d'azote en conditions gnotobiotiques. La souche bactérienne la plus efficiente en modèle spermosphère était la souche NO4O d'Azospirillum brasilense, qui apparaissait significativement plus efficiente que la souche NO13 d' Enterobacter cloacae, utilisée comme référence et dont l'efficience était représentative de la plupart des isolats étudiés. Cette souche a été inoculée au riz, au semis et au repiquage dans 2 stations expérimentales du delta du Nil. L'inoculation de la souche NO4O, dans les deux cas, s'est traduite par un accroissement significatif de la récolte $(0,01<\mathrm{P}<0,05)$. L'effet était d'autant plus marqué que la fertilisation azotée était plus élevée et atteignait 15\% à Sakha et $20 \%$ à Gemmeiza. L'effet semble concerner surtout les composantes tardives du rendement.

PGPR - Azospirillum brasilense - modèle spermosphère - récolte - inoculation

\section{INTRODUCTION}

Studies on plant-growth-promoting rhizobacteria (PGPR) have proliferated over recent years (Davison, 1988), but the concept of PGPR is still vague. Occasionally it has been applied to bacteria which have been studied for positive effects on plant growth such as phosphate solubilization (Mishustin and Naumova, 1962), nitrogen fixation or hormone production (Gaskins et al., 1985). More recently, it has been used for other phenomena such as the antagonism against plant pathogens (Burr and Caesar, 1984), the ability to increase plant physiological processes, or plant tolerance to a great variety of stresses. The only common feature is the beneficial effect observed on crops following inoculation.
Common difficulties in all studies of PGPR responses are : the necessity to screen large numbers of plants; the lack of correlation between in vitro and in situ results; and the inconsistency of observed effects on crops. Nitrogenfixing bacteria associated with cereals provide a good example of the problems involved. Their positive effects on plant growth were established long ago (see for instance, Truffaut and Bezssonnof, 1925) and their use on a large scale was attempted, then abandoned, in the Soviet Union in the forties (Rubenchik, 1963). Following the discovery (Day and Döbereiner, 1975) that Azospirillum was a common inhabitant of grass rhizospheres, their use again became tashionable in the late seventies. This enthusiasm abated when it became evident that the ability of a 
bacterium to positively affect plant growth could not be reliably predicted.

During a study of the dominant $\mathrm{N}_{2}$-fixing bacteria associated with the roots of rice, ThomasBauzon et al. (1982) designed a gnotobiotic experimental model which they named the spermosphere model. Among other purposes this model showed large differences among strains in their ability to fix nitrogen in association with their host plants under gnotobiotic conditions in vitro. Inoculation with the most efficient strain (Azospirillum lipoferum 4B), increased yields of rice under field conditions (Charyulu et al., 1985).

To further evaluate the predictive value of the in vitro behaviour of strains associated with sterile plantlets, a study was conducted on two Egyptian soils. A great diversity was observed amongst the most abundant $\mathrm{N}_{2}$-fixing bacteria (Omar et al., 1988) which included Enterobacter cloacae, E. agglomerans, Citrobacter freundii, Klebsiella planticola and Azospirillum brasilense. The efficiency of each of these isolates was measured in spermosphere models (Heulin et al., 1989 ) and $A$. brasilense NO40 was found to be the most efficient. This article describes the use of this strain to inoculate rice in situ in Egypt.

\section{MATERIALS AND METHODS}

\section{Bacterial strains}

Strain NO40 of Azospirillum brasilense was isolated from a 10-3 dilution of a rice rhizosphere soil, originally taken from the Moshtohoor experimental station, 50 $\mathrm{km}$ North of Cairo. The soil sample was used to grow rice cv. Giza 171 in a phytotron for $8 \mathrm{~d}$ until nitrogenase activity was high (Omar et al., 1988). Among 23 strains of $\mathrm{N}_{2}$-fixing bacteria compared in vitro in spermosphere model, strain NO40 is 2 to 5 times more active than most strains isolated from this soil (Heulin et al., 1989).

\section{Stations}

Inoculation trials were performed at 2 different experimental stations in the Nile delta, viz. (1) Gemmeiza,
120 and (2) Sakha, $150 \mathrm{~km}$ north of Cairo, respectively. Table I summarizes some properties of the soils in the above areas.

\section{Experimental design}

In the 2 experiments, the effect of inoculation was compared to the effect of a regular nitrogen fertilization. The maximum rate of $N$ fertilizer $(96 \mathrm{~kg} \mathrm{~N} / \mathrm{ha}$ in Sakha and $76 \mathrm{~kg} \mathrm{~N} / \mathrm{ha}$ in Gemmeiza) was the rate recommended by the Ministry of Agriculture for the location and in consideration of the previous crop. A zero $\mathrm{N}$ treatment and a medium $\mathrm{N}$ treatment (48 and $38 \mathrm{~kg} \mathrm{~N} / \mathrm{ha}$, respectively) were included. Control plots were inoculated with a heat-killed inoculum. Plots were randomized inside blocks.

\section{Inoculation}

Bacteria were grown to maximum density $\left(10^{9} \mathrm{cells} / \mathrm{ml}\right)$ in Difco nutrient broth. Bags filled with seeds were soaked in water for $24 \mathrm{~h}$ then kept warm for another $24 \mathrm{~h}$ under a layer of decomposing manure, following traditional practice. Germinated seeds were placed in large basins overnight in contact with the bacterial suspension or its autoclaved counterpart. Each inoculated seed received approximately $10^{6}$ bacteria. Nurseries were sown the next morning. Care was taken to avoid cross-contamination : plots were separated by mud bands, $50 \mathrm{~cm}$ wide inside blocks and $1 \mathrm{~m}$ wide between blocks, and water was prevented from flowing between plots. At transplanting, young plantlets were inoculated again by soaking their roots overnight in a similar bacterial suspension.

\section{Fertilizers}

A trace amount of $\mathrm{N}$ was applied to the nursery beds, along with $11 \mathrm{~kg} \mathrm{ZnSO}_{4} /$ ha to avoid $\mathrm{Zn}$ deficiency.

Before transplanting, the plots received a $\mathrm{PK}$ fertilization equivalent to $35.7 \mathrm{~kg} \mathrm{P}_{2} \mathrm{O}_{5}$ and $57.1 \mathrm{~kg} \mathrm{~K} 2 \mathrm{O} / \mathrm{ha}$. Nitrogen fertilization (ammonium sulfate) was split : half the rate was applied before tillering between 16 and $23 \mathrm{~d}$ after transplanting (July 13, 1985, in Gemmeiza; July 27 in Sakha), the other half was applied 17 d later.

\section{Cultivation}

Nursery beds ware sown on May 16 in Gemmeiza and May 28 in Sakha. At the same date zinc sulfate was

Table I. Soil characteristics of the stations in which inoculation trials were conducted (Sakha and Gemmeiza) and of the station where NO40 was isolated (Moshtohoor).

$\begin{array}{llllll}\text { Station } & \text { Clay (\%) } & \mathrm{C} / \mathrm{N} & \mathrm{Total} N(\%) & \mathrm{pH} & \mathrm{CaCO}_{3}(\%)\end{array}$

$\begin{array}{llllll}\text { Sakha } & 59.8 & 13.6 & 0.088 & 8.5 & 3.17 \\ \text { Gemmeiza } & 59.9 & 13.1 & 0.137 & 8.4 & 2.91 \\ \text { Moshtohoor } & 58.6 & 11.8 & 0.136 & 8.3 & 3.08\end{array}$


applied. Trace amounts of $\mathrm{N}$ were applied on June 5 and 16, respectively. Transplanting was done on June 28 in Gemmeiza and July 4 in Sakha, 2 weeks after the soil had been waterlogged. Flowering occurred on August 30 and September 7. No pesticides were used; nevertheless, development of algae was extremely low. Plots were weeded by hand, and hoed after water removal at each fertilizer application. Birds were repelled.

\section{Harvest}

Plots were harvested on October 26 and 22, 120 and $110 \mathrm{~d}$ after transplanting, at Gemmeiza and Sakha, respectively. Harvest was done by hand, using a sickle. Determinations were made of grain and shoot dry matter, nitrogen content, 1000 grains dry weight, panicle dry matter.

\section{Statistics}

Classical variance analyses were performed. Studied factors were : $\mathrm{N}$ fertilizer, inoculation and blocks. Each experimental station was treated separately.

\section{RESULTS AND DISCUSSION}

At both locations, a clear-cut effect of nitrogen fertilizer $(P=1 \%)$ was found, suggesting that nitro- gen was actually the limiting factor of yield and $\mathrm{N}$ exported with harvest (Table II and III). This effect of fertilizer was also found for the $\mathrm{N}$-content of the grain (Table IV), but not for the weight of 1000 grains (Table $\mathrm{V}$ ). As grain $\mathrm{N}$ - content mainly depends upon remobilization of foliar proteins, whereas the weight of 1000 grains is a late component of yield, we assume that the effect of $N$ fertilizer is an early effect on plant $\mathbf{N}$ nutrition. At the time of tiller initiation, this effect was still observable in Sakha (Table VI), but it was absent in Gemmeiza (no effect of $\mathrm{N}$ on this parameter; Table VI), perhaps due to the lower supply of $\mathrm{N}$ fertilizer.

Inoculation had a positive significant effect on yield and $\mathrm{N}$ exported with harvest. This effect was observed mainly on late components of yield, such as the weight of 1000 grains (Table V) which is not affected by $\mathrm{N}$ fertilizers.

Thus, there seems to be a balance between : an effect of fertilizers on early components of yield ( $\mathrm{N}$ content of grains, number of fertile tillers in Sakha); an effect of inoculation on the filling of grain, a late component of yield, as if the period of active photosynthesis was extended by inoculation. At the same time, it must be emphasized (data not shown) that, in both stations, inoculation had a significant effect on the panicle length

Table II. Design of the field experiments. Effect of inoculation and of 3 rates of nitrogen fertilizer on grain yield $\left(\mathrm{kg} / 10 \mathrm{~m}^{2}\right.$ which can be extrapolated to $\mathrm{T} / \mathrm{ha}$ ).

\begin{tabular}{|c|c|c|c|c|c|c|}
\hline Station & & Gemmeiza & & & Sakha & \\
\hline Previous crop & & Clover & & & Barley & \\
\hline Plot size $\left(\mathrm{m}^{2}\right)$ & & 20 & & & 14 & \\
\hline Replicates & & 6 & & & 8 & \\
\hline $\mathrm{N}, \mathrm{kg} / \mathrm{ha}$ & 0 & 38 & 76 & 0 & 48 & 96 \\
\hline Killed inoculum & 9.33 & 9.87 & 11.09 & 5.91 & 6.83 & 7.55 \\
\hline $\begin{array}{l}\text { Live inoculum } \\
\text { Fertilizer effect } \\
\text { Inoculum effect }\end{array}$ & 9.95 & $\begin{array}{ll} & 11.49 \\
\text { s } & (P=1 \%) \\
\text { s } & (P=1 \%)\end{array}$ & 13.44 & 6.22 & $\begin{array}{l}7.10 \\
\text { s }(P=1 \%) \\
\text { s }(P=5 \%)\end{array}$ & 8.75 \\
\hline
\end{tabular}

Grain weights refer to a $14 \%$ water content. Variation coefficients are $13.3 \%$ in Gemmeiza and $11.6 \%$ in Sakha. Respective SDs are 14.5 and 8.2 .

Table III. Effect of inoculation and of 3 rates of nitrogen fertilizer on the total nitrogen exported with harvest (kg N/ha).

\begin{tabular}{lcccccc}
\hline Station & \multicolumn{3}{c}{ Gemmeiza } & \multicolumn{3}{c}{ Sakha } \\
\hline $\mathrm{N}, \mathrm{kg} / \mathrm{ha}$ & 0 & 38 & 76 & 0 & 48 & 96 \\
Killed inoculum & 95.5 & 108.0 & 126.0 & 56.4 & 85.3 & 80.7 \\
Live inoculum & 101.3 & 117.5 & 156.1 & 67.5 & 79.7 & 122.3 \\
Fertilizer effect & & $\mathrm{s}(P=1 \%)$ & & & $\mathrm{s}(P=1 \%)$ & \\
inoculum effect & & $\mathrm{s}(P=5 \%)$ & & & $\mathrm{s}(P=1 \%)$
\end{tabular}


Table IV. Effect of inoculation and of 3 rates of nitrogen fertilizer on the nitrogen content of grain (\%).

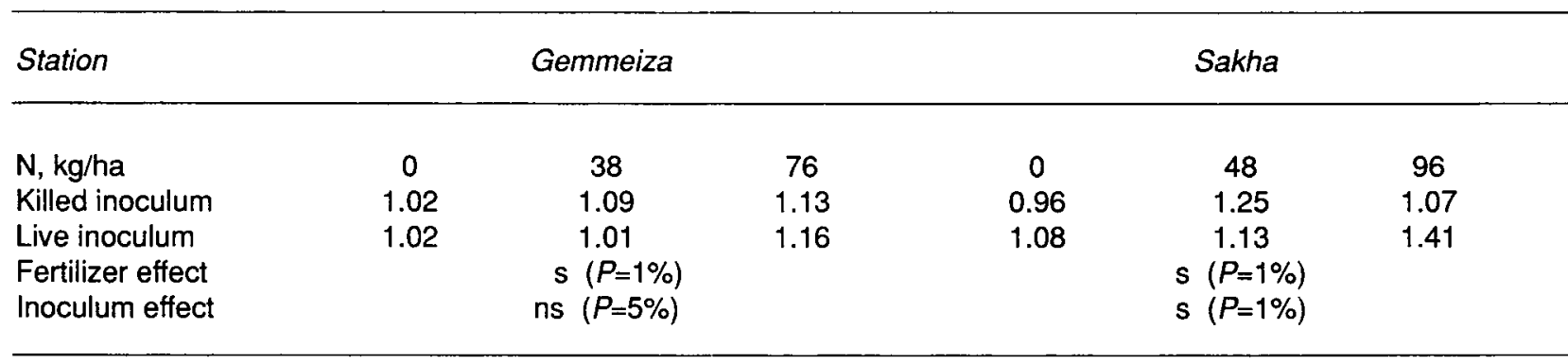

Variation coefficients are $5.1 \%$, and $2.3 \%$ in Gemmeiza and Sakha, respectively. Respective SDs are 0.06 and 0.03 .

Table V. Effect of inoculation and of the 3 rates of nitrogen fertilizer on the weight of 1000 grains (in g).

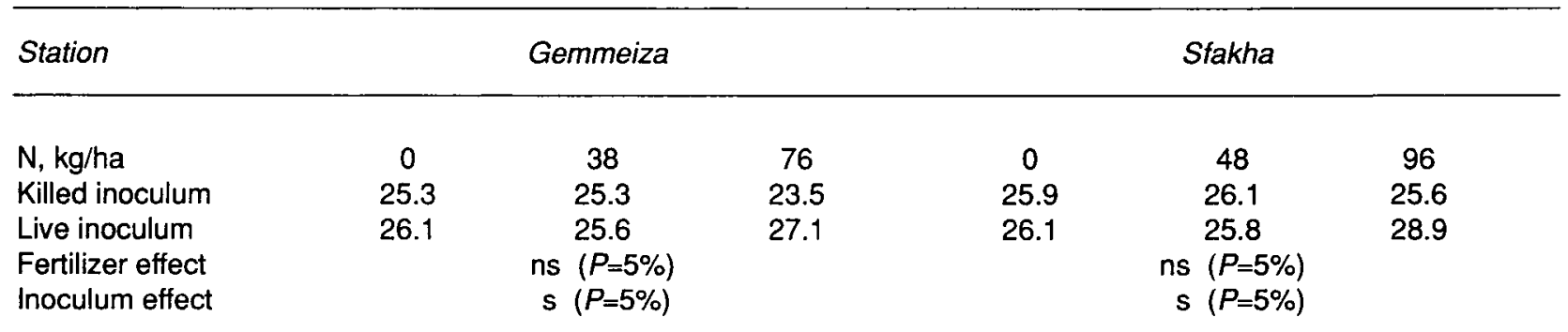

Variation coefficients are $6.6 \%$ and $6.9 \%$ in Gemmeiza and Sakha, respectively. Respective SDs are 1.69 and 1.83.

Table VI. Effect of inoculation and of the 3 rates of nitrogen fertilizer on the number of fertile tillers per hill.

\begin{tabular}{|c|c|c|c|c|c|c|}
\hline Station & & Gemmeiza & & & Sakha & \\
\hline $\mathrm{N}, \mathrm{kg} / \mathrm{ha}$ & 0 & 38 & 76 & 0 & 48 & 96 \\
\hline Killed inoculum & 23 & 17 & 23 & 15 & 19 & 18 \\
\hline $\begin{array}{l}\text { Live inoculum } \\
\text { Fertilizer effect } \\
\text { Inoculum effect }\end{array}$ & 21 & $\begin{array}{ll} & 23 \\
\text { ns } & (P=5 \%) \\
\text { ns } \quad(P=5 \%)\end{array}$ & 25 & 17 & $\begin{array}{c}19 \\
\text { s }(P=1 \%) \\
\text { s }(P=5 \%)\end{array}$ & 24 \\
\hline
\end{tabular}

Variation coefficients are $29.0 \%$ and $21.0 \%$ in Gemmeiza and Sakha, respectively. Respective SDs are 6.42 and 3.94.

$(1 \%<P<5 \%)$, whereas $\mathrm{N}$ fertilizer only stimulated length in Sakha.

As confirmed in 3 subsequent field experiments (reported elsewhere), seed inoculation of rice by Azospirillum NO40 thus appears to mimic the effect of $\mathrm{N}$ fertilizers beyond their probable time of exhaustion.

The effect of inoculation on yield in the absence of added $N$ is low : $+5 \%$ in Sakha, and $+6 \%$ in Gemmeiza. At the highest fertilization rate it is surprisingly high : $+15 \%$ in Sakha, and $+21 \%$ in Gemmeiza (Table II and Fig. 1). Obviously, in this experiment there is no antagonism between nitrogen fertilizers and the effect of inoculation by bacteria. On the contrary, a synergistic effect does exist in many cases, as shown by the presence of significant interactions between the ino- culation and fertilizer factors. For instance, on the weight of 1000 grains, this interaction is significant ( $P=2 \%$ in Sakha and ca. $5 \%$ in Gemmeiza), the corresponding $F$ values being 4.60 and 3.34 , respectively.

This effect of inoculation was observed under conditions when $\mathrm{N}$ was the actual limiting factor of growth, as shown by the yield of controls increasing with the rate of $\mathrm{N}$ fertilization. In another experiment (data not shown), where the controls did not respond to $\mathrm{N}$ application, no effect of inoculation was observed. This supports the hypothesis that Azospirillum acts through the nitrogen nutrition of rice.

At the end of the vegetative growth phase, photosynthesis and exudation are maximum and nitrogen fertilizer usually exhausted. These 


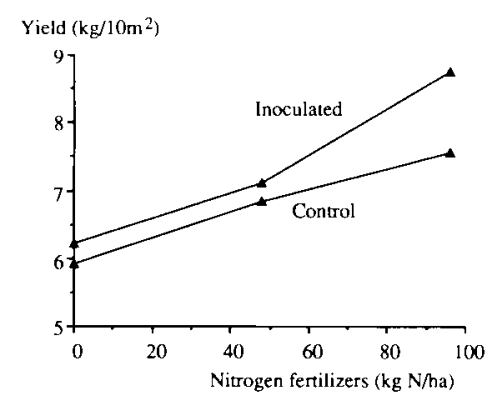

Fig. 1. Sakha experimental station; effect on yield of Azospirillum brasilense NO40 inoculation, compared to the effect of nitrogen fertilizers.

conditions are clearly conducive to a high nitrogenase activity (Balandreau and Ducerf, 1980) which, in turn, could supply inoculated plants with extra nitrogen, enabling photosynthesis to extend longer into the grain-filling period. Other explanations are also possible : if Azospirillum acts through hormone production rather than nitrogen fixation, extended root development may open access to an extended pool of soil nitrogen, so improving the fertilizer use. In the absence of labelled nitrogen fertilizers, the 2 mechanims cannot be distinguished, for both of them would similarly affect the apparent increase in fertilizer use. Table III shows that there is such an increase in the apparent coefficient of fertilizer use (increase in exported $\mathrm{N}$, in percentage of the corresponding increase in $\mathrm{N}$ fertilizer) : increases in $\mathrm{N}$ exported with harvest are approximately $40 \%$ of increases in N fertilizer in Gemmeiza and 30\% in Sakha for controls, whereas for inoculated plots they apparently reach $70 \%$ and $60 \%$ respectively. Moreover, it must be stressed that nitrogen fixation and hormonal effects are not exclusive mechanisms and could work synergistically.

Whatever the underlying mechanism, the practice of cereal inoculation should not be regarded as a substitute for nitrogen fertilizers, but as, a simple means of extending their effect beyond economically feasible rates. Nor is inoculation a practice for inefficient agricultures : the yield levels of rice reported here are among the highest in the world. Figure 2 emphasizes the 2 extreme types of situation in which inoculation can be considered : in developing countries in which the cost of nitrogen fertilizers is a limiting factor, the use of seed inoculation would allow for an increase in yield without increasing fertilizer consumption. In developed countries where very high rates of nitrogen fertilizers are used, pollution is often a concern : in this situation, seed inoculation can be used to decrease the fertilizer application while keeping yield constant.

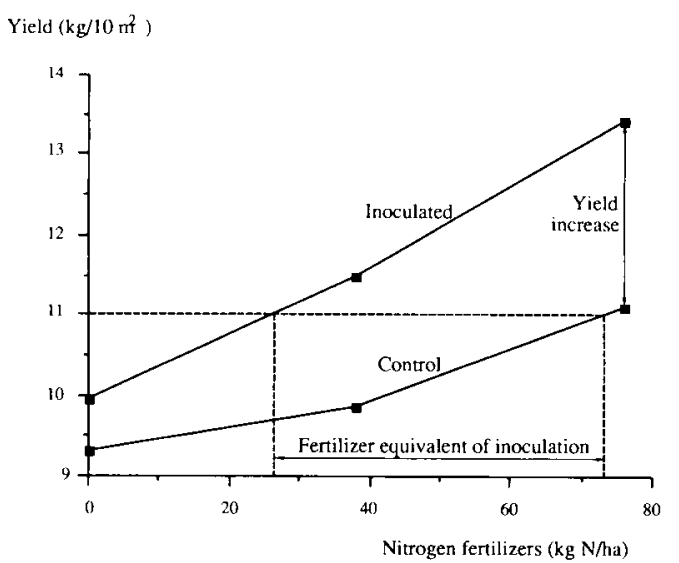

Fig. 2. Gemmeiza experimental station; effect on yield of Azospirillum brasilense NO40 inoculation, compared to the effect of nitrogen fertilizers. A same level of yield, e.g. $11 \mathrm{~T} / \mathrm{ha}$ can be obtained by applying $70 \mathrm{~kg} \mathrm{~N} / \mathrm{ha}$ of nitrogen fertilizers, or alternatively by inoculating the plant and using only $25 \mathrm{~kg} \mathrm{~N} / \mathrm{ha}$. The effect of inoculation is thus equivalent to the use of $45 \mathrm{~kg} \mathrm{~N} / \mathrm{ha}$ at this level of yield.

\section{ACKNOWLEDGMENT}

This research was supported financially by the EEC program on Tropical Agriculture. NO received a double channel fellowship from the Egyptian and the French governments. The Centre de Pédologie Biologique du CNRS is associated with Nancy I University. We are very grateful to Professor $W$. Broughton for his comments on the manuscript, and to Y. Abou Zeid and $M$. Abd El Gaward for their technical assistance.

\section{REFERENCES}

Balandreau J. \& Ducerf P. (1980) Analysis of factors limiting nitrogenase $\left(\mathrm{C}_{2} \mathrm{H}_{2}\right)$ activity in the field. Nitrogen Fixation (W.E. Newton \& W.H. Orme-Johnson, eds.), University Park Press, Baltimore, pp. 229-242

Burr T.J. \& Cesar A. (1984) Beneficial plant bacteria. Crit. Rev. Plant Sci. 2, 1-20

Charyulu P.B.B.N., Fourcassié F., Barbouche A.K., Rondro-Harisoa L., Omar A.M.N, Weinhard P., Marie R. \& Balandreau J. (1985) Field inoculation of rice using in vitro selected bacterial and plant genotypes. Azospirillum III (Klingmüller, ed.) Experientia (suppl.) pp. $163-179$

Davison J. (1988) Plant beneficial bacteria. Biotechnol. $6,282-286$

Day J. \& Döbereiner J. (1975) Physiological aspects of $\mathrm{N}_{2}$ fixation by a Spirillum from Digitaria roots. Soil. Biol. Biochem. 7, 45-50

Gaskins M.H., Albrecht S.L. \& Hubbel D.H. (1985) Rhizosphere bacteria and their use to increase plant productivity : a review. Agric. Ecosyst. Environ. 12, 99-116 Heulin T., Rahman M., Omar A.M.N., Rafidison Z., Pierrat J.C. \& Balandreau J. (1989) Experimental and mathematical procedures for comparing efficiencies of rhizosphere $\mathrm{N}_{2}$-fixing bacteria. J. Microbiol. Methods 9 , 163-173

Mishustin E.N. \& Naumova A.N. (1962) Bacterial fertilizers, their effectiveness and mode of action. Mikrobiologiya 31, 543-545 
Omar A.M.N., Richard Cl., Weinhard P. \& Balandreau J. (1988) Using the spermosphere model technique to describe the dominant $\mathrm{N}_{2}$-fixing microflora associated with wetland rice in two Egyptian soils. Biol. Fertil. Soils 7, 158-163

Rubenchik L.I. (1963) Azotobacter and its use in agriculture. Israel program for scientific translations, Jerusalem
Thomas-Bauzon D., Weinhard P., Villecourt P. \& Balandreau J. (1982) The spermosphere model. I : Its use in growing, counting and isolating nitrogen-fixing bacteria from the rhizosphere of rice. Can J. Microbiol. $28,922-928$

Truffaut G. \& Bezssonoff N. (1925) Fixation de l'azote gazeux par des plantes supérieures autres que des légumineuses. Sci. Sol 4, 1-56 